\title{
Perancangan Warning System Berbasis SMS Gateway Pada Pajak Kendaraan Bermotor Di Samsat Kota Padang
}

\author{
Rinaldi Dwi Putra Mooduto', Firman Surya², Rasyidah Mustika ${ }^{3}$
}

\author{
${ }^{1}$ Politeknik Negeri Padang \\ Email: rdpmooduto@yahoo.com \\ 2 Jurusan Akuntansi, Politeknik Negeri Padang \\ Email: firm4n2003@gmail.com \\ 3Jurusan Akuntansi Politeknik Negeri Padang \\ Email: titik.mustika@gmail.com
}

\begin{abstract}
ABSTRAK
Penelitian ini bertujuan untuk merancang, mendesain, dan menguji fasilitas layanan informasi berbasis SMS gateway sehingga dapat membantu pihak SAMSAT kota Padang dalam meningkatkan pelayanan pada pajak kendaraan bermotor. Penelitian ini merupakan penelitian action research. Perancangan sistem yang akan dibangun, dibuat dengan bentuk rancangan desain tabel, desain input, dan desain output. Pengujian yang dilakukan menggunakan data uji berupa pengolahan data, pengolahan proses, dan pengolahan laporan. Hasil dari penelitian ini adalah terciptanya sebuah sistem informasi SMS gateway yang dapat memberikan informasi kepada pihak SAMSAT Padang maupun pihak masyarakat pemilik STNK mengenai jatuh tempo masa berlaku STNK bagi pengguna kendaraan.
\end{abstract}

Kata kunci: SMS Gateway, Warning System, Pajak Kendaraan Bermotor.

\section{ABSTRACT}

This study aims to design, design, and test information service ased on SMS gateway so that it can help the SAMSAT Padang in improving services on motor vehicle tax collection process. The design of the system to be built, consist of table design, input design, and output design. Tests conducted using test data. The result of this research is the creation of an SMS gateway information system prototype that can provide information to SAMSAT Padang and owner of motor vehicle concerning their vehicle tax obligation.

Keywords: SMS Gateway, Warning System, Vehicle Tax.

\section{Pendahuluan}

\section{Latar Belakang}

Pajak dapat diartikan sebagai sumber dana dari sebuah negara untuk mengatasi berbagai masalah seperti masalah sosial, peningkatan kesejahteraan, kemakmuran serta menjadi kontrak sosial antara pemerintah dengan warga negaranya. Faktorfaktor yang mempengaruhi penerimaan pajak suatu negara adalah pertumbuhan ekonomi. Pertumbuhan ekonomi akan meningkatkan pendapatan masyarakat yang tentunya akan berpengaruh langsung terhadap kemampuan masyarakat secara finansial untuk membayar pajak.

Di kota Padang, pajak daerah menyumbang jumlah yang cukup besar bagi pendapatan asli daerah. Salah satu jenis pajak daerah yaitu pajak kendaraan bermotor. Pemungutan pajak kendaraan bermotor merupakan jenis pemungutan 
yang sudah lama dilakukan oleh pemerintah. Pajak ini sangat berpengaruh terhadap sumber pendapatan asli daerah, yang berguna untuk membiayai pelaksanaan tugas rutin pemerintah daerah. Maka pemungutan penerimaan pajak ini perlu dioptimalkan sebaik mungkin. Hanya saja penerimaan pajak kendaraan bermotor ini tidak sesuai dengan ekspektasinya. Di kota Padang, tunggakan pajak kendaraan bermotor masih dirasakan setiap tahunnya.

Berikut data tunggakan pajak kendaraan bermotor yang diperoleh dari Badan Keuangan Daerah Provinsi Sumatera Barat:

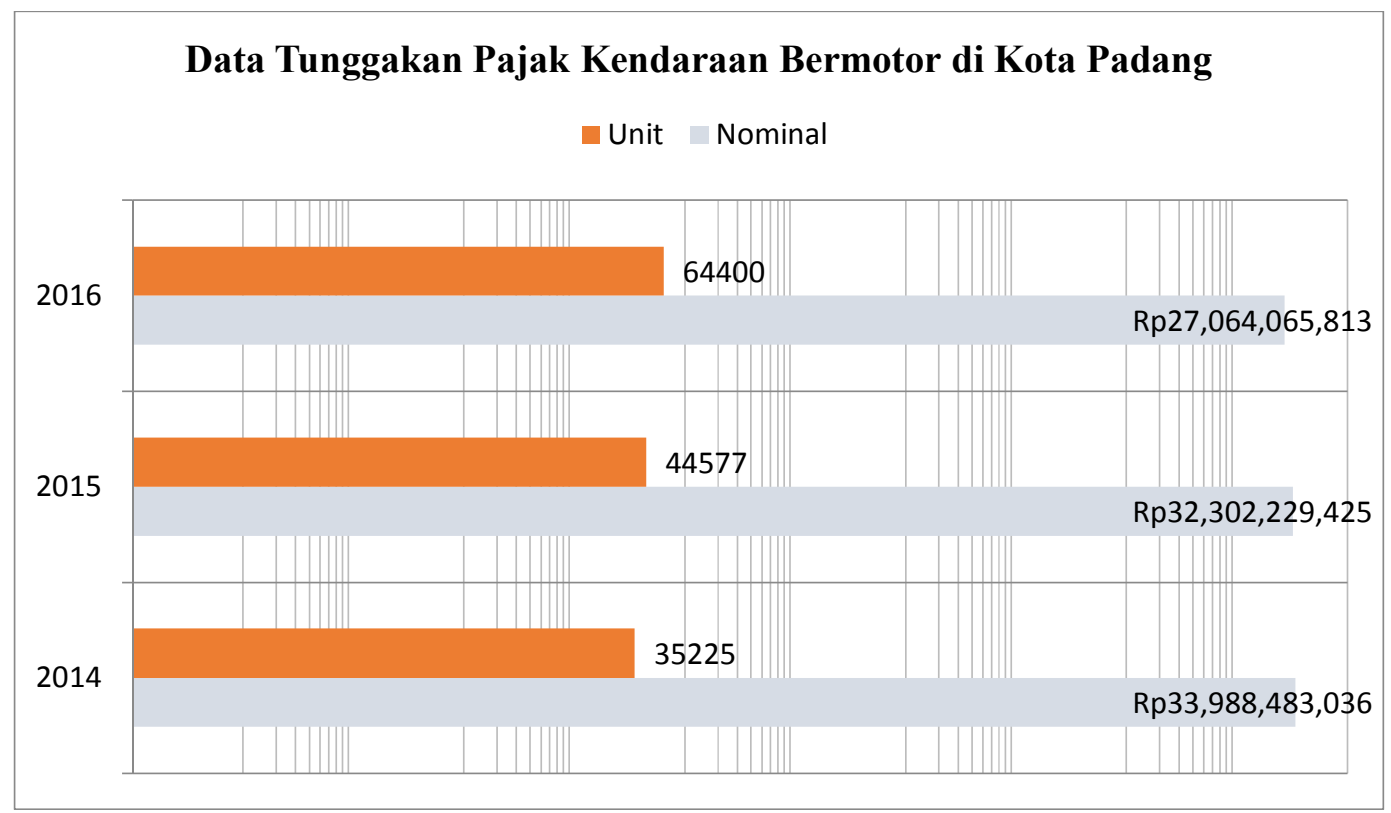

Gambar 1. Data Tunggakan Pajak Kendaraan Bermotor di Kota Padang

Berdasarkan dari gambar di atas, penulis menyimpulkan bahwa adanya peningkatan dalam tunggakan pajak kendaraan bermotor di daerah Padang dari tahun ke tahun. Maka dari itu, perlunya peningkatan layanan untuk mengoptimalkan penerimaan pajak kendaraan bermotor. Seiring dengan perkembangan teknologi yang semakin maju, kebutuhan akan informasi juga semakin tinggi. Salah satu produk teknologi yaitu SMS (Short Message Service) dimana produk teknologi ini telah menjadi salah satu media untuk mendapatkan informasi tanpa harus terikat tempat dan waktu. SMS gateway adalah sebuah teknologi yang memungkinkan kita melakukan pengiriman dan penerimaan teks short message service melalui teknologi GSM di komputer. Dipilihnya teknologi SMS gateway untuk sistem informasi pengingat jatuh tempo masa berlaku STNK pada pengguna kendaraan ini, karena teknologi SMS yang sudah sangat akrab dengan sebagian orang dan untuk menggunakannya pun sangat mudah dan masih banyak lagi kelebihan dan kemudahan yang ditawarkan dalam menerapkan SMS gateway di dalam pembuatan sistem yang akan dijalankan.

Penulis menganggap sistem ini cukup penting dikarenakan sangat membantu pihak SAMSAT Padang bagian STNK dan pemilik kendaraan dalam memperlancar pelayanan dan peningkatan infrastruktur informasi STNK. Selain itu, sistem ini juga dapat membantu pemilik STNK dalam mendapatkan informasi secara lengkap dan tentunya akurat mengenai jatuh tempo STNK mereka masing-masing. Kebutuhan 
serta kepentingan masyarakat harus diutamakan pada setiap pemerintahan. Pelayanan publik berperan penting dalam pemerintahan karena menyangkut akan kepentingan masyarakat luas. Kurniawan dalam Sinambela (2006) pelayanan publik merupakan pemberian layanan kepada masyarakat yang memiliki kepentingan dengan instansi untuk mencapai tujuan bersama.

Peningkatan pelayanan publik pemerintah selalu dituntut untuk memberikan pelayanan yang efektif, efisien dan berkualitas. Peningkatan pelayanan publik yang dilakukan oleh pemerintah salah satunya melalui program-program inovatif yang berorientasi pada kepuasan pengguna layanan (Rahmayanti, 2013). Penulis ingin merancang sistem agar dapat meningkatkan pelayanan informasi mengenai jatuh tempo masa berlaku STNK secara interaktif antara pihak SAMSAT Padang dan masyarakat pemilik STNK, sehingga tercipta sebuah sistem informasi yang mencapai tujuan dari penelitian ini yang nantinya masyarakat dapat merasakan dampak positif dari tercapainya peningkatan mutu dan pelayanan.

\section{Rumusan Masalah}

Berdasarkan latar belakang yang telah di uraikan sebelumnya, maka yang menjadi topik permasalahan untuk dijadikan titik tolak pembahasan dalam penelitian ini yaitu bagaimana merancang, mendesain, dan menguji sistem peringatan dini jatuh tempo pajak kendaraan bermotor yang akan dilakukan pada SAMSAT kota Padang?

\section{Tujuan Penelitian}

Adapun tujuan yang ingin dicapai dari penelitian ini yaitu:

1. Untuk merancang, mendesain, dan menguji fasilitas layanan informasi berbasis SMS gateway.

2. Untuk membantu SAMSAT kota Padang meningkatkan pelayanan dalam pajak kendaraan bermotor.

\section{Manfaat Penelitian}

Adapun manfaat dari penelitian ini bagi pihak SAMSAT Padang yaitu:

1. Menjadi sebuah acuan yang nantinya dapat dijadikan dasar untuk meningkatkan fungsi dan layanan pengembangan sistem informasi warning jatuh tempo STNK pada pengguna kendaraan bermotor.

2. Pendorong dalam pengembangan teknologi yang diharapkan sesuai dapat memberikan manfaat tersendiri bagi pengguna kendaraan.

\section{Metode Penelitian}

Metode yang digunakan dalam penelitian ini adalah action research. Action research merupakan salah satu bentuk rancangan penelitian, dalam penelitian tindakan peneliti mendeskripsikan, menginterpretasi dan menjelaskan suatu situasi sosial pada waktu yang bersamaan dengan melakukan perubahan atau intervensi dengan tujuan perbaikan atau partisipasi. 


\section{Metode Pengumpulan Data}

Dalam melakukan penelitian untuk mendapatkan data dan informasi, maka metode yang digunakan dalam proses pengumpulan data sebagai berikut:

1. Wawancara

Metode pengumpulan data dengan cara mendatangi secara langsung pihakpihak intern kantor SAMSAT Padang yang mempunyai wewenang untuk memberikan informasi. Sehingga informasi yang didapat lebih lengkap, akurat, dan benar.

\section{Observasi}

Metode ini dilakukan dengan cara mengamati langsung objek yang berhubungan dengan masalah yang diambil di lingkungan SAMSAT Padang pada bagian STNK mengenai data kepemilikan kendaraan.

\section{Metode Pengembangan Sistem}

Metode pengembangan sistem pada penelitian ini menggunakan metode System Development Life Cycle (SDLC). SDLC adalah metodologi tradisional yang digunakan untuk pengembangan, pemeliharaan, penggantian sistem informasi. Berikut adalah tahapan-tahapan metode pengembangan sistem SDLC:

1. Pemilihan dan Identifikasi Proyek

Fase pertama SDLC mencakup kegiatan: mengidentifikasi, menganalisa, menentukan prioritas, dan penyusunan kebutuhan menyeluruh proyek sistem informasi organisasi/perusahaan. Pada tahap ini di identifikasi kebutuhan sistem informasi untuk pengembangan atau perbaikan sistem yang baru.

2. Perencanaan dan Inisialisasi Proyek

Fase kedua dari SDLC adalah perencanaan dan inisialisasi proyek, pada fase ini menjelaskan/mengemukakan apakah proyek sistem informasi layak untuk dilanjutkan atau tidak. Perencanaan detil, termasuk juga pengembangan untuk tahap selanjutnya dari SDLC. Kegiatan utama pada fase ini yaitu: Preliminary (persiapan); Investigation (investigasi permasalahan sistem) atau peluang (opportunity); alasan mengapa sistem harus dikembangkan atau tidak. Langkah penting pada fase ini adalah keputusan untuk menentukan ruang lingkup (scope) sistem yang akan diajukan, termasuk rencana spesifik proyek sistem informasi, rencana waktu dan kebutuhan sumber daya.

\section{Analisis}

Fase ketiga dari SDLC adalah analisis. Analisis dilakukan dalam beberapa sub fase, yaitu: pertama, menentukan kebutuhan (needs requirement) sistem, kegiatan ini dilakukan secara bersama-sama antara analis dan user; kedua, mempelajari kebutuhan dan struktur hubungan diantara kebutuhankebutuhan sistem tersebut agar tidak terjadi redundancy (saling tumpang tindih); ketiga, generalisasi alternatif desain awal (initial design) agar sesuai dengan kebutuhan; keempat, bandingkan alternatif-alternatif tersebut sehingga sesuai dengan biaya, sumber daya, dan tingkatan teknik sehingga tercapai kesepakatan untuk proses pengembangan sistem informasi. Hasil akhir dari tahap analisis adalah berupa rekomendasi alternatif solusi pengembangan sistem informasi. 


\section{Desain Logika}

Fase keempat dari SDLC adalah desain logika, yaitu gambaran fungsi-fungsi sistem yang dipilih dari pengembangan sistem dalam analisis yang independen dan platform komputernya. Pada fase ini dilakukan konversi dari rekomendasi alternatif solusi pengembangan sistem informasi ke dalam spec (spesifikasi) logika dan fisik. Kegiatan utama pada fase ini yaitu: desain input; desain ouput; desain database.

5. Desain Fisik

Desain fisik yaitu merupakan transformasi (konversi) dari desain logika ke desain fisik/teknikal (rincian spec teknologi) dari mulai programming sampai dengan penyelesaian konstruksi sistem. Pada desain fisik tim analis harus menetapkan: bahasa pemprograman yang akan dipakai, system database, struktur file, platform H/W, operating system, dan lingkungan jaringannya. Hasil akhir dari tahap desain fisik adalah berupa spec. Desain fisik yang akan diserahkan ke programer atau ke pembangun sistem yang lainnya untuk konstruksi sistem.

6. Pengujian

Metode pengujian yang digunakan adalah metode black box. Black box adalah pengujian yang dilakukan hanya mengamati hasil eksekusi melalui data uji dan memeriksa fungsional dari perangkat lunak. Jadi dianalogikan seperti kita melihat suatu kotak hitam, kita hanya bisa melihat penampilan luarnya saja, tanpa tau ada apa dibalik bungkus hitamnya. Sama seperti pengujian black box, mengevaluasi hanya dari tampilan luarnya (interface-nya), fungsionalitasnya, tanpa mengetahui apa sesungguhnya yang terjadi dalam proses detilnya (hanya mengetahui input dan output).

\section{Hasil dan Pembahasan}

\section{Analisis sistem}

Ini adalah fase ketiga dalam metode System Development Life Cycle (SDLC). Hal yang dilakukan pada fase ini, yaitu mempelajari sistem yang sedang berjalan (current system) dan alternatif sistem yang akan diajukan. Penulis mempelajari prosedur yang sedang berjalan dan sistem informasi yang digunakan untuk menjalankan aktivitas (task) organisasi/perusahaan.

\section{Analisis sistem yang sedang berjalan}

Pelayanan STNK pada SAMSAT Padang selama ini tidak ada media untuk membuat sistem peringatan jatuh tempo STNK pada masyarakat sekitar. Sehingga masih banyak masyarakat yang lupa akan jatuh tempo STNK mereka masing-masing. Selain itu, untuk meningkatkan pelayanan teknologi informasi kepada masyarakat dirasakan penting untuk membangun sistem warning (pengingat) jatuh tempo STNK kepada pengguna kendaraan. Disini tidak hanya pihak SAMSAT yang merasa diuntungkan dalam hal peningkatan pelayanan teknologi kepada masyarakat tetapi juga sangat menguntungkan bagi pihak pemilik STNK (masyarakat sekitar).

\section{Analisis sistem yang akan diajukan}

Sebagai upaya memaksimalkan pelayanan jasa kepada masyarakat luas, maka diajukanlah pembangunan suatu sistem warning (pengingat khusus) yang nantinya 
diharapkan dapat memberikan informasi yang up to date dari kantor SAMSAT kepada para pemilik STNK mengenai jatuh tempo STNK mereka.

\section{Rancangan Sistem}

Pada perancangan sistem yang akan dibangun, dibuat dengan menggunakan metode pengembangan daur hidup (System Development Life Cycle) yang terdiri dari beberapa tahapan yaitu perencanaan, analisis, perancangan dan evaluasi.

\section{Perencanaan}

Pada tahap perencanaan, penulis mempelajari permasalahan yang ada yaitu pelayanan STNK pada kantor SAMSAT Padang selama ini tidak ada media untuk membuat sistem peringatan jatuh tempo STNK pada masyarakat sekitar. Sehingga masih banyak masyarakat yang lupa akan jatuh tempo STNK mereka masing-masing. Hal ini dapat dilihat pada data perpanjangan STNK, maka dari itu dirasakan penting untuk membangun warning (pengingat) jatuh tempo STNK kepada pemilik STNK. Di sini tidak hanya pihak kepolisian yang merasa diuntungkan dalam hal peningkatan pelayanan teknologi kepada masyarakat, tetapi juga sangat menguntungkan bagi pihak pemilik STNK (masyarakat sekitar).

\section{Analisis}

Pada tahap analisis, penulis akan menganalisis permasalahan secara lebih mendalam dengan menyusun suatu studi kelayakan dan menganalisis kebutuhan perangkat.

1. Studi kelayakan

Studi kelayakan merupakan proses menganalisis masalah yang akan diteliti dengan suatu tinjauan mengenai faktor-faktor utama yang akan mempengaruhi kemampuan sistem untuk mencapai tujuan yang diinginkan. Dengan demikian sistem yang dikembangkan pada penelitian ini dinilai kelayakan teknis, ekonomis dan operasional.

a. Kelayakan teknis

Dinilai dari segi kelayakan teknis, kantor SAMSAT mempunyai sumber daya teknis yang dapat mendukung di dalam mengimplementasikan sistem ini nantinya.

b. Kelayakan ekonomis

Pembuatan aplikasi dari sistem ini diharapkan dapat memberikan manfaat bagi SAMSAT dan juga tentunya bagi masyarakat pemilik STNK. Dari segi manfaat yang dihasilkan sistem ini dapat berguna bagi yang menggunakannya.

c. Kelayakan operasional

Aplikasi dari sistem ini didesain seefektif mungkin, sehingga tidak mempersulit pengguna dalam mendapatkan informasi yang dibutuhkan dengan mudah dan cepat.

2. Analisis kebutuhan perangkat

Tahap analisis kebutuhan perangkat adalah tahapan pengumpulan kebutuhankebutuhan dari semua elemen sistem perangkat yang akan dibangun. Pada 
tahap ini dibentuk spesifikasi kebutuhan perangkat, fungsi perangkat sistem, performansi (unjuk kerja) sistem perangkat yang akan dibuat. Adapun perangkat keras dan perangkat lunak yang dibutuhkan antara lain:

a. Perangkat keras yang dibutuhkan untuk menjalankan sistem SMS gateway tersebut memenuhi spesifikasi berikut:

1) Komputer dengan processor $2.0 \mathrm{Ghz}$, hardisk berkapasitas $500 \mathrm{Mb}$ atau lebih, RAM berkapasitas minimal $256 \mathrm{Mb}$, monitor, keyboard, dan mouse.

2) CD ROM atau slot USB.

3) Modem GSM atau Mobile Phone yang dapat terkoneksi dengan PC.

b. Perangkat lunak yang dibutuhkan untuk mengembangkan dan membangun sistem informasi tersebut adalah XAMPP 5.6.31 yang sudah menyangkut PHP dan basis data MySQL. Kemudian Gammu seri 1.38.4 yang digunakan sebagai SMS gateway dan web browser.

\section{Perancangan}

Berdasarkan analisa dari sistem yang ada, maka diusulkan suatu program aplikasi pengolahan data yang berbasis intranet dan hanya dijalankan oleh admin, sehingga membantu pelaksanaan dalam jalannya aplikasi warning (pengingat) jatuh tempo STNK khususnya di bagian operator STNK pada SAMSAT Padang. Pada proses perancangan sistem yang akan dibangun, dibuat dengan menggunakan beberapa bentuk rancangan yaitu desain tabel, desain input dan desain output.

\section{Evaluasi}

Tahap ini dilakukan uji coba sistem yang telah disusun. Proses uji coba diperlukan untuk memastikan bahwa sistem prosedur sudah benar, sesuai dengan kebutuhan pengguna, sesuai karakteristik yang diterapkan dan tidak ada kesalahan-kesalahan yang terkandung di dalamnya.

\section{Rancangan Basis Data}

Basis data merupakan sistem yang terdiri atas kumpulan file (tabel) yang saling berhubungan dalam sebuah basis data di sebuah sistem komputer yang memungkinkan untuk mengakses dan memanipulasi file-file (tabel-tabel) tersebut. Pada sistem SMS gateway ini terdapat 4 tabel, diantaranya adalah: tabel user, tabel SMS, tabel registrasi dan tabel info pemilik STNK.

\section{Rancangan Struktur Menu}

Rancangan struktur menu merupakan rancangan tampilan dari sistem yang akan dikembangkan. Dari rancangan halaman login sampai rancangan halaman logout. 


\section{Desain Sistem}

Pada langkah ini penulis membuat rencana tentang kebutuhan perangkat lunak mengenai warning system pajak kendaraan bermotor melalui SMS gateway terlihat seperti gambar berikut:

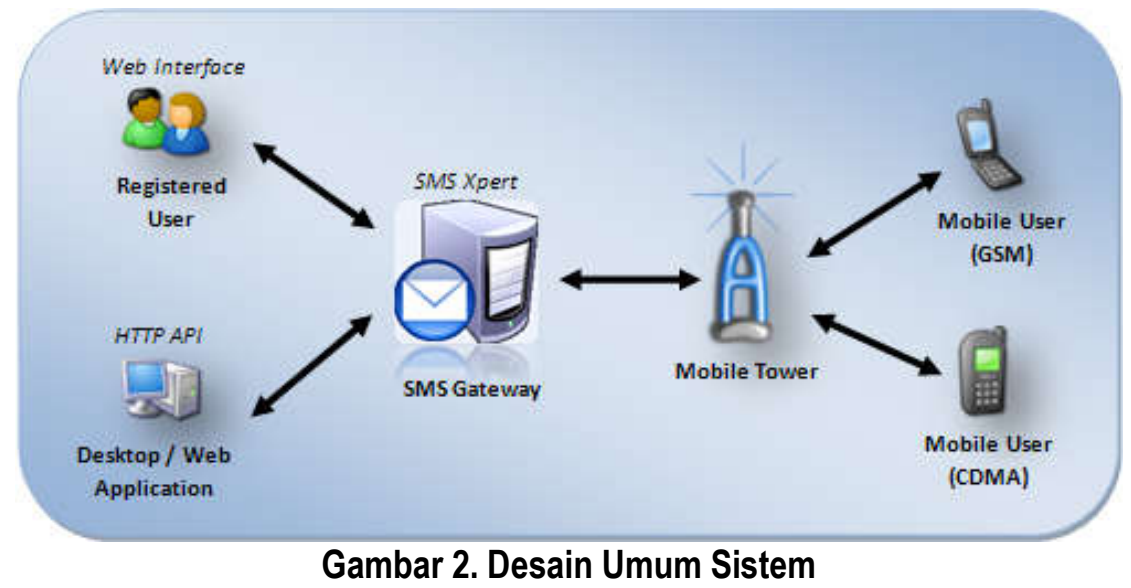

\section{Flowchart}

\section{Login admin}

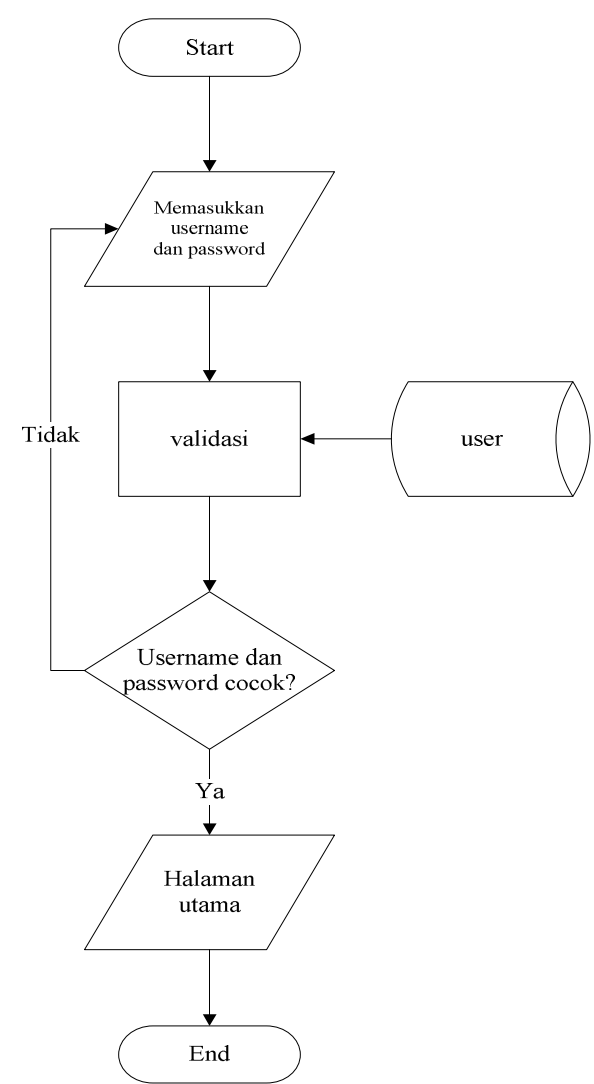

Gambar 3. Flowchart Login Admin 
Gambar 3 menjelaskan alur dari proses login. Di sini admin harus memasukkan username dan password terlebih dahulu. Selanjutnya akan dilakukan proses validasi. Jika username dan password benar, maka akan berlanjut ke proses selanjutnya. Dan jika tidak, maka akan kembali pada proses awal.

\section{Entry data pemilik STNK}

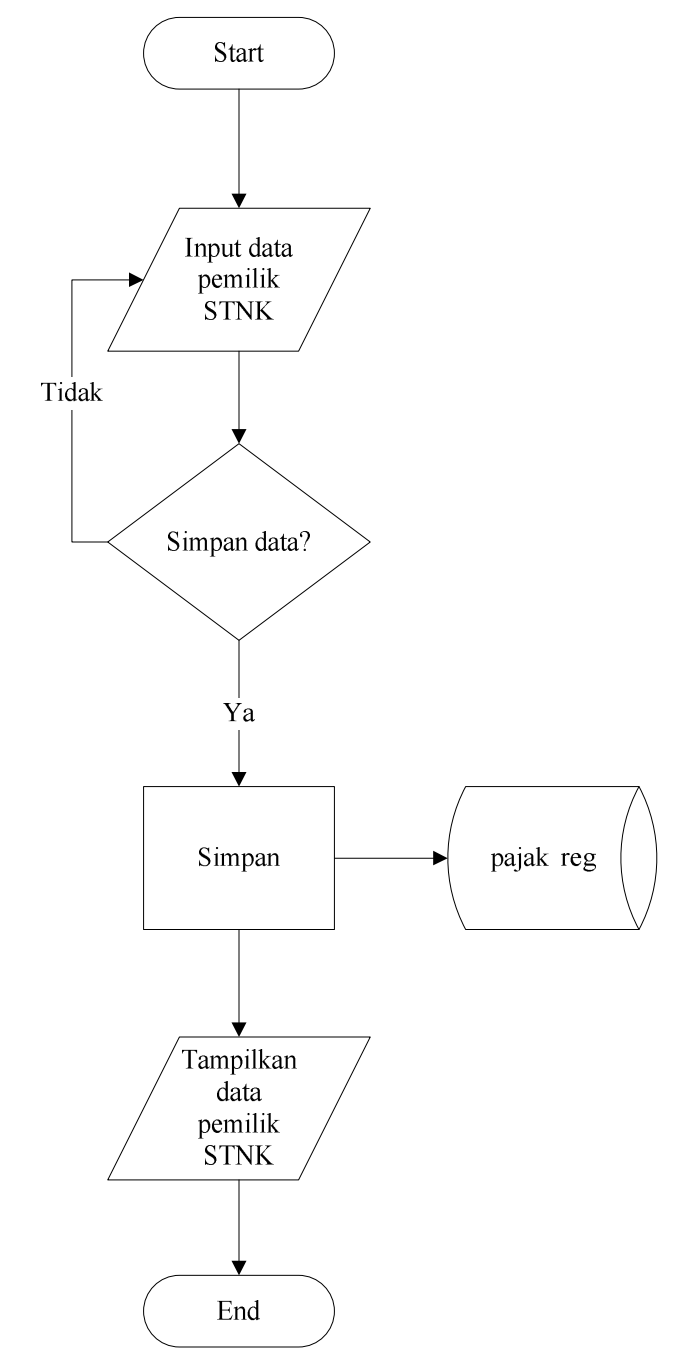

Gambar 4. Flowchart Entry Data Pemilik STNK

Gambar 4 menjelaskan tentang proses input data pemilik STNK ke dalam database yang sudah disiapkan. Dimulai dari mengisikan data-data pemilik STNK, dan kemudian akan diproses untuk menyimpan ke database. 


\section{Informasi pemilik STNK}

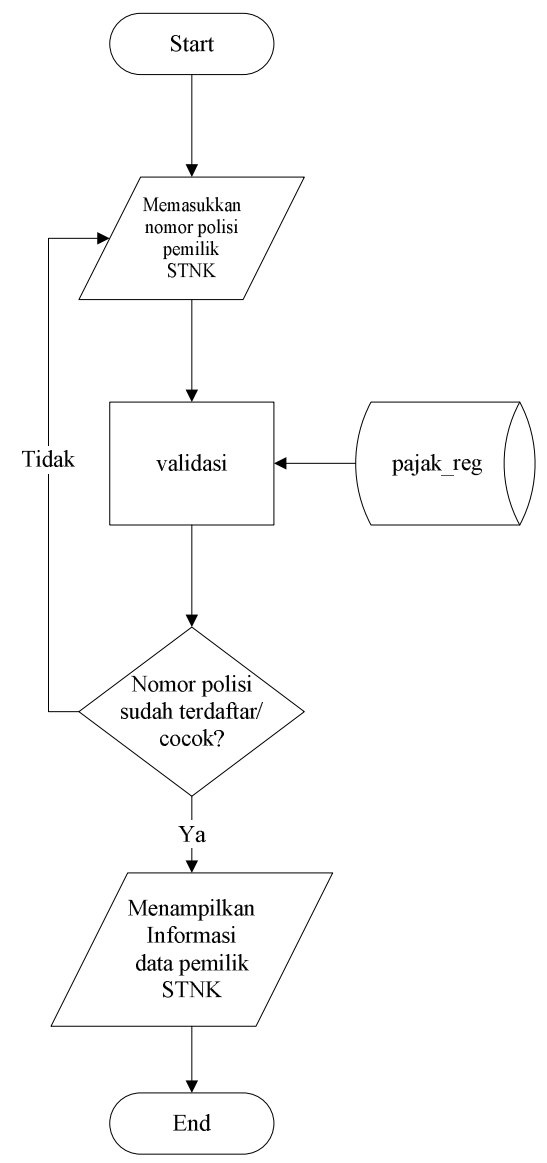

Gambar 5. Flowchart Informasi Data Pemilik STNK

Gambar 5 menjelaskan alur dari proses untuk melihat informasi data pemilik STNK. Di sini pemilik STNK harus memasukkan nomor polisi yang telah terdaftar terlebih dahulu. Selanjutnya akan dilakukan proses validasi. Jika nomor polisi benar, maka akan berlanjut ke proses selanjutnya. Dan jika tidak, maka akan kembali pada proses awal.

\section{Data Flow Diagram (DFD)}

Pembuatan data flow diagram ini dengan maksud untuk mengetahui logika dan alur dari sistem yang akan dibangun.

\section{Diagram konteks SMS gateway}

Pada gambar 6 dapat dilihat bahwa sistem SMS gateway memiliki dua external entity yaitu admin dan pemilik STNK. Penjelasan singkat dari gambar di atas adalah pemilik STNK nantinya akan mendapatkan peringatan dini jatuh tempo pajak kendaraan bermotor yang telah diatur oleh sistem dan admin bertugas untuk memasukkan data dari pemilik STNK jika ada data baru atau perubahan data. 


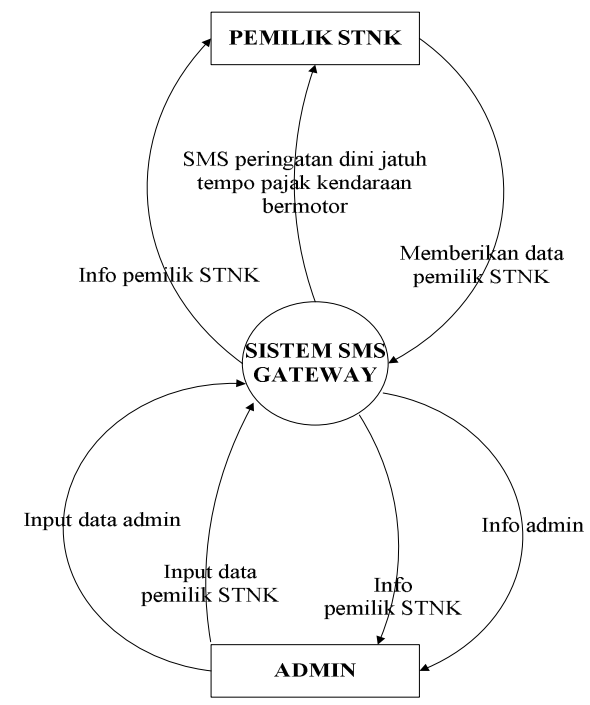

\section{Gambar 6. Diagram Konteks SMS Gateway}

\section{Diagram alir data (data flow diagram) SMS gateway level 0}

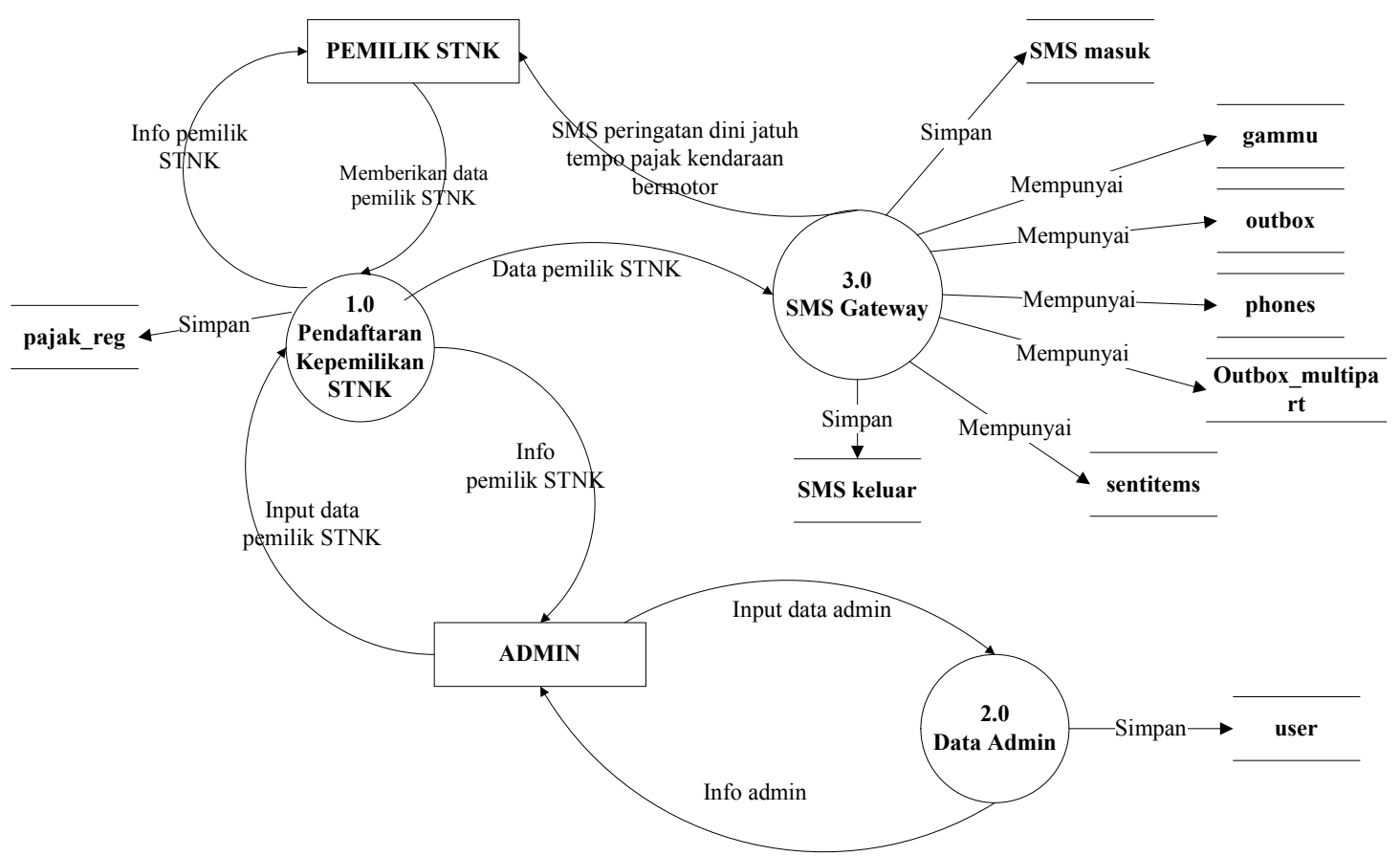

\section{Gambar 7. Diagram Alir Data SMS Gateway Level 0}

\section{Desain Tabel}

Tahap ini adalah perancangan desain tabel untuk keperluan sistem SMS gateway yang ditunjukkan pada tabel berikut:

Tabel 1. User

\begin{tabular}{|l|l|}
\hline \multicolumn{1}{|c|}{ Field } & \multicolumn{1}{c|}{ Tipe } \\
\hline Username & Varchar (100) \\
\hline Password & Varchar (255) \\
\hline
\end{tabular}




\begin{tabular}{|l|l|}
\hline \multicolumn{1}{|c|}{ Field } & \multicolumn{1}{c|}{ Tipe } \\
\hline Level & $\operatorname{Int}(2)$ \\
\hline Status & $\operatorname{lnt}(1)$ \\
\hline
\end{tabular}

Tabel 2. Gammu

\begin{tabular}{|l|c|}
\hline \multicolumn{1}{|c|}{ Field } & Tipe \\
\hline Version & $\operatorname{lnt}(11)$ \\
\hline
\end{tabular}

Tabel 3. Inbox

\begin{tabular}{|l|l|}
\hline \multicolumn{1}{|c|}{ Field } & \multicolumn{1}{c|}{ Tipe } \\
\hline Updated in database & Time stamp \\
\hline Receiving date time & Time stamp \\
\hline Text & Text \\
\hline Sender number & Varchar (20) \\
\hline Coding & Enum \\
\hline UDH & Text \\
\hline SMSC number & Varchar (20) \\
\hline Class & Int (11) \\
\hline Text decoded & Text \\
\hline ID & Int (10) unsigned \\
\hline Recipient ID & Text \\
\hline Processed & enum \\
\hline
\end{tabular}

Tabel 4. Outbox

\begin{tabular}{|l|l|}
\hline \multicolumn{1}{|c|}{ Field } & \multicolumn{1}{c|}{ Tipe } \\
\hline Updated in database & Time stamp \\
\hline Insert into database & Time stamp \\
\hline Sending date time & Time stamp \\
\hline Send before & Time \\
\hline Send after & Time \\
\hline Text & Text \\
\hline Destination number & Varchar (20) \\
\hline Coding & Enum \\
\hline UDH & Text \\
\hline Class & Int (11) \\
\hline Text decoded & Text \\
\hline ID & Int (10) unsigned \\
\hline Multipart & Enum \\
\hline Relative validity & Int (11) \\
\hline Sender ID & Varchar (255) \\
\hline Sending time out & Time stamp \\
\hline Delivery report & Enum \\
\hline Creator ID & Text \\
\hline
\end{tabular}

Tabel 5. Outbox Multipart

\begin{tabular}{|l|l|}
\hline \multicolumn{1}{|c|}{ Field } & \multicolumn{1}{c|}{ Tipe } \\
\hline Text & Text \\
\hline Coding & Enum \\
\hline UDH & Text \\
\hline Class & Int (11) \\
\hline Text decoded & Text \\
\hline ID & Int (10) unsigned \\
\hline Sequence position & Int (11) \\
\hline
\end{tabular}


Tabel 6. Registrasi Pajak

\begin{tabular}{|l|l|}
\hline \multicolumn{1}{|c|}{ Field } & \multicolumn{1}{c|}{ Tipe } \\
\hline Nomor registrasi & Varchar (10) \\
\hline Pemilik & Varchar (50) \\
\hline Alamat & Varchar (150) \\
\hline Merk/tipe & Varchar (50) \\
\hline Jenis & Varchar (25) \\
\hline Tahun buat & Int (4) \\
\hline Warna & Varchar (20) \\
\hline Silinder & Int (4) \\
\hline Nomor rangka & Varchar (30) \\
\hline Nomor mesin & Varchar (30) \\
\hline Nomor BPKB & Varchar (30) \\
\hline Bahan bakar & Varchar (20) \\
\hline Warna TNKB & Varchar (10) \\
\hline Nomor polisi lama & Varchar (10) \\
\hline Berat kendaraan bermotor & Int (5) \\
\hline Jumlah sumbu & Int (3) \\
\hline JBB penumpang & Int (3) \\
\hline Nomor urut & Varchar (25) \\
\hline No. SKUM & Varchar (25) \\
\hline No. KOHIR & Varchar (25) \\
\hline BBNKB pokok & Double \\
\hline BBNKB denda & Double \\
\hline PKB pokok & Double \\
\hline PKB denda & Double \\
\hline SWDKLLJ pokok & Double \\
\hline SWDKLLJ denda & Double \\
\hline Adm STNK & Double \\
\hline Adm TNKB & Double \\
\hline Tempo & Date \\
\hline Nomor HP & Varchar (20) \\
\hline & \\
\hline
\end{tabular}

Tabel 7. Phones

\begin{tabular}{|l|l|}
\hline \multicolumn{1}{|c|}{ Field } & \multicolumn{1}{c|}{ Jenis } \\
\hline ID & Text \\
\hline Updated in database & Time stamp \\
\hline Insert into database & Time stamp \\
\hline Time out & Time stamp \\
\hline Send & Enum \\
\hline Receive & Enum \\
\hline IMEI & Varchar (35) \\
\hline Client & Text \\
\hline Battery & Int (11) \\
\hline Signal & $\operatorname{Int}(11)$ \\
\hline Sent & $\operatorname{Int}(11)$ \\
\hline Received & $\operatorname{Int}(11)$ \\
\hline
\end{tabular}

Tabel 8. Sent Items

\begin{tabular}{|l|l|}
\hline \multicolumn{1}{|c|}{ Field } & \multicolumn{1}{c|}{ Jenis } \\
\hline Updated in database & Time stamp \\
\hline Insert into database & Time stamp \\
\hline Sending date time & Time stamp \\
\hline Delivery date time & Time stamp \\
\hline Text & Text \\
\hline Destination number & Varchar (20) \\
\hline Coding & Enum \\
\hline
\end{tabular}




\begin{tabular}{|l|l|}
\hline \multicolumn{1}{|c|}{ Field } & \multicolumn{1}{c|}{ Jenis } \\
\hline UDH & Text \\
\hline SMSC number & Varchar (20) \\
\hline Class & Int (11) \\
\hline Text decoded & Text \\
\hline ID & Int (10) unsigned \\
\hline Sender ID & Varchar (255) \\
\hline Sequence position & Int (11) \\
\hline Status & Enum \\
\hline Status error & Int (11) \\
\hline TPMR & Int (11) \\
\hline Relative validity & Int (11) \\
\hline Creator ID & Text \\
\hline
\end{tabular}

\section{Rencana Pengujian}

Pengujian aplikasi pengolahan data berikut menggunakan data uji berupa pengolahan data, pengolahan proses dan pengolahan laporan serta informasi kelengkapannya.

Tabel 9. Rencana Pengujian

\begin{tabular}{|l|l|l|}
\hline \multicolumn{1}{|c|}{ Kelas Uji } & \multicolumn{1}{c|}{ Butir Ujian } & \multicolumn{1}{c|}{ Jenis Pengujian } \\
\hline Login & Login & Black box \\
\hline Pengolahan data & $\begin{array}{l}\text { Pengolahan data registrasi, info } \\
\text { pemilik kendaraan, SMS }\end{array}$ & Black box \\
\hline Proses informasi & SMS informasi jatuh tempo pajak & Black box \\
\hline
\end{tabular}

\section{Pengujian}

Menjalankan pada sistem informasi warning jatuh tempo STNK pada kantor SAMSAT Padang khusunya bagian Dispenda berbasis SMS gateway ini secara langsung harus mempunyai server web local yaitu XAMPP, aplikasi ini mempunyai halaman utama atau halaman depan yaitu halaman index yang berfungsi sebagai halaman utama secara otomatis pada saat aplikasi ini diaktifkan oleh admin.

Disini, penulis menggunakan PHP sebagai tampilan untuk menjalankan aplikasi SMS gateway. Hasil dari pembuatan program bantuan PHP ini memiliki sub-sub menu sebagai berikut:

1. Menu utama merupakan halaman utama saat kita mengetik address dan langsung link ke halaman utama admin. Halaman ini berfungsi sebagai halaman informasi yang dibutuhkan dan login untuk admin.

2. Menu registrasi info pajak via SMS merupakan pendataan kembali identitas pemilik STNK, dengan catatan ada penambahan nomor handphone yang nantinya akan digunakan untuk pengiriman SMS gateway.

3. Menu info pajak merupakan halaman yang berfungsi untuk melihat informasi pajak kendaraan bermotor dari pemilik STNK.

4. Menu welcome admin merupakan link dari halaman login. Pada halaman ini admin dapat melakukan beberapa aktivitas yang menyangkut proses pengiriman SMS gateway.

5. Menu SMS notifikasi merupakan halaman yang berfungsi untuk mengirim SMS ke nomor handphone pemilik STNK yang telah didaftarkan. SMS yang akan dikirimkan secara otomatis dengan rentang waktu 2 bulan, 1 bulan, dan 1 minggu sebelum jatuh tempo masa berlaku STNK. SMS yang telah dikirim 
nantinya berisi tentang informasi kendaraan pemilik STNK, tanggal jatuh tempo, dan nilai pajak yang akan dibayar. Jika pemilik STNK telah melewati jatuh tempo masa berlaku STNK (menunggak), maka SMS akan dikirimkan setiap bulan dengan format pesan yang sama beserta denda.

6. Menu ubah password merupakan halaman yang digunakan oleh admin untuk mengubah password.

Pengujian terhadap sistem telah dilakukan dan berhasil dilakukan dengan baik, bebas dari kesalahan dan secara umum diperoleh hasil yang sesuai dengan apa yang diharapkan. Berikut ini adalah tabel pengujian aplikasi:

Tabel 4.10 Pengujian Aplikasi

\begin{tabular}{|c|c|c|c|}
\hline \multicolumn{4}{|c|}{ Hasil Uji } \\
\hline Data Masukan & Yang diharapkan & Pengamatan & Kesimpulan \\
\hline $\begin{array}{l}\text { Login user ID dan } \\
\text { password benar }\end{array}$ & $\begin{array}{l}\text { Menampilkan form menu } \\
\text { utama }\end{array}$ & $\begin{array}{l}\text { Menu utama berhasil } \\
\text { ditampilkan }\end{array}$ & Diterima \\
\hline $\begin{array}{l}\text { Login user ID benar dan } \\
\text { password salah }\end{array}$ & $\begin{array}{l}\text { Muncul pesan salah } \\
\text { password }\end{array}$ & $\begin{array}{l}\text { Pesan "Password Salah" } \\
\text { muncul }\end{array}$ & Diterima \\
\hline $\begin{array}{l}\text { Pengolahan data kirim } \\
\text { SMS }\end{array}$ & $\begin{array}{l}\text { Akan tampil data kirim } \\
\text { SMS kepemilikan } \\
\text { kendaraan yang terdiri } \\
\text { dari nomor polisi, nama } \\
\text { pemilik, alamat, nomor } \\
\text { HP, dan tanggal jatuh } \\
\text { tempo }\end{array}$ & $\begin{array}{l}\text { Pengolahan data } \\
\text { informasi kirim SMS }\end{array}$ & Diterima \\
\hline $\begin{array}{l}\text { Pengolahan data daftar } \\
\text { registrasi }\end{array}$ & $\begin{array}{l}\text { Maka akan tampil data } \\
\text { daftar registrasi telepon } \\
\text { yang terdiri dari nomor } \\
\text { polisi, nama pemilik dan } \\
\text { nomor HP }\end{array}$ & $\begin{array}{l}\text { Pengolahan data } \\
\text { informasi daftar registrasi }\end{array}$ & Diterima \\
\hline $\begin{array}{l}\text { Pengolahan data info } \\
\text { pajak }\end{array}$ & $\begin{array}{l}\text { Maka akan tampil data } \\
\text { pemilik kendaraan yang } \\
\text { terdiri dari nomor polisi, } \\
\text { jenis kendaraan, } \\
\text { merk/tipe, tahun } \\
\text { pembuatan, warna, } \\
\text { tanggal jatuh tempo serta } \\
\text { rincian biaya dari pajak } \\
\text { kendaraan bermotor } \\
\text { pemilik STNK }\end{array}$ & $\begin{array}{l}\text { Pengolahan data info } \\
\text { pajak }\end{array}$ & Diterima \\
\hline
\end{tabular}

\section{Kesimpulan dan Saran}

\section{Kesimpulan}

Berdasarkan dari hasil penelitian ini, dapat disimpulkan bahwa:

Penelitian ini sebagaimana sudah dirancang, didesain, dan diuji sehingga menghasilkan sebuah sistem informasi berbasis SMS gateway yang dapat memberikan informasi kepada pihak SAMSAT Padang maupun pihak masyarakat pemilik STNK mengenai jatuh tempo masa berlaku STNK bagi pengguna kendaraan. Dengan adanya peningkatan layanan sistem berbasis SMS gateway pada pajak kendaraan bermotor, dapat membantu pihak SAMSAT kota Padang dan masyarakat pemilik STNK dalam memperlancar pelayanan dan peningkatan infrastruktur informasi STNK. Selain itu, sistem ini juga dapat membantu pemilik STNK dalam 
mendapatkan informasi secara lengkap dan tentunya akurat mengenai jatuh tempo STNK mereka masing-masing.

\section{Saran Penelitian}

Saran untuk peneliti selanjutnya, melihat adanya peningkatan penerimaan pajak atau penurunan tunggakan pajak setelah sistem ini diterapkan pada kantor SAMSAT di kota Padang.

Penelitian mengenai perancangan SMS gateway tidak hanya sampai disini. Untuk kedepannya penulis mengharapkan sistem yang dirancang lebih efektif dan memiliki menu database yang lebih detail.

\section{Referensi}

[1] Ahmad, Afridian, Wirahadi. (2015). Kajian Potensi Pajak Daerah Kota Padang. Universitas Andalas.

[2] Ardiani, Leli. (2016). Jurnal Perpajakan (JEJAK). Implementasi Layanan Inovasi Samsat Keliling Dalam Upaya Meningkatkan Pelayanan Pembayaran Pajak Kendaraan Bermotor (Studi Pada Kantor Bersama SAMSAT Kabupaten Tulungagung), 9 (1).

[3] Chandra, Gregorius., dan Adriana, Dadi. (2015). Sistem Informasi Akuntansi Konsep dan Penerapan. Yogyakarta: CV Andi Offset.

[4] Churchman, West. (2011). Sistem Informasi Akuntansi. (Terjemahan Krismiaji). Jakarta: Salemba Empat.

[5] Donovan, Deny. (2015). Jurnal Ilmu \& Riset Akuntansi. Strategi Pemungutan PBB Sebagai Upaya Meningkatkan Pendapatan Asli Daerah Di Kota Mojokerto.

[6] Hall, A., James. (2007). Sistem Informasi Akuntansi (edisi ke-4). Jakarta: Salemba Empat.

[7] Kabuhung, Merystika. (2013). Jurnal EMBA. Sistem Informasi Akuntansi Penerimaan dan Pengeluaran Kas Untuk Perencanaan dan Pengendalian Keuangan Pada Organisasi Nirlaba Keagamaan, 1 (3), 339-348.

[8] Krismiaji. (2005). Sistem Informasi Akuntansi. Yogyakarta: UPP AMP YKPN

[9] Kustiyaningsih, Yeni. (2010). Pemrograman Basis Data Berbasis Web Menggunakan PHP dan MySQL. Bangkalan: Graha Ilmu.

[10] Madya, S. (2006). Teori dan Praktik Penelitian Tindakan (Action Research). Bandung: Alfabeta.

[11] Megawati, D., Abdullah., dan Bakti, M. (2012). Jurnal Imiah Implementasi dan Pengujian SMS Gateway sebagai Media Alert Warning Jatuh Tempo Pajak Kendaraan Bermotor. Implementasi Dan Pengujian Sms Gateway Sebagai Media Alert Warning Jatuh Tempo Pajak Kendaraan Bermotor. 
[12] Nuryamin. (2016). Inovasi Pelayanan Pajak Kendaraan Bermotor UPTD Kantor SAMSAT Makassar. Skripsi. Fakultas Ilmu Sosial Dan Ilmu Politik Universitas Hasanuddin.

[13] Nuryani, Sri, Endah. (2010). Analisis Pajak Hotel di Kabupaten Bandung. Jakarta.

[14] Peraturan Daerah Provinsi Sumatera Barat Nomor 4 Tahun 2011 Tentang Pajak Daerah.

[15] Puspitawati, Lilis., dan Anggadini, Sri, Dewi. (2011). Sistem Informasi Akuntansi. Jakarta: Graha Ilmu.

[16] Rahmayanti, Nina. (2013). Manajemen Pelayanan Prima. Yogyakarta: Graha Ilmu.

[17] Saputra, Agus. (2011). Trik dan Solusi Jitu Pemrograman PHP. Jakarta: IKAPI.

[18] Sinambela, L Poltak. (2006). Reformasi Pelayanan Publik. Teori Kebijakan dan Implementasi. Jakarta: PT Bumi Aksara.

[19] Undang-Undang RI Nomor 28 Tahun 2009 Tentang Pajak Daerah dan Retribusi Daerah. 